Provided for non-commercial research and education use. Not for reproduction, distribution or commercial use.

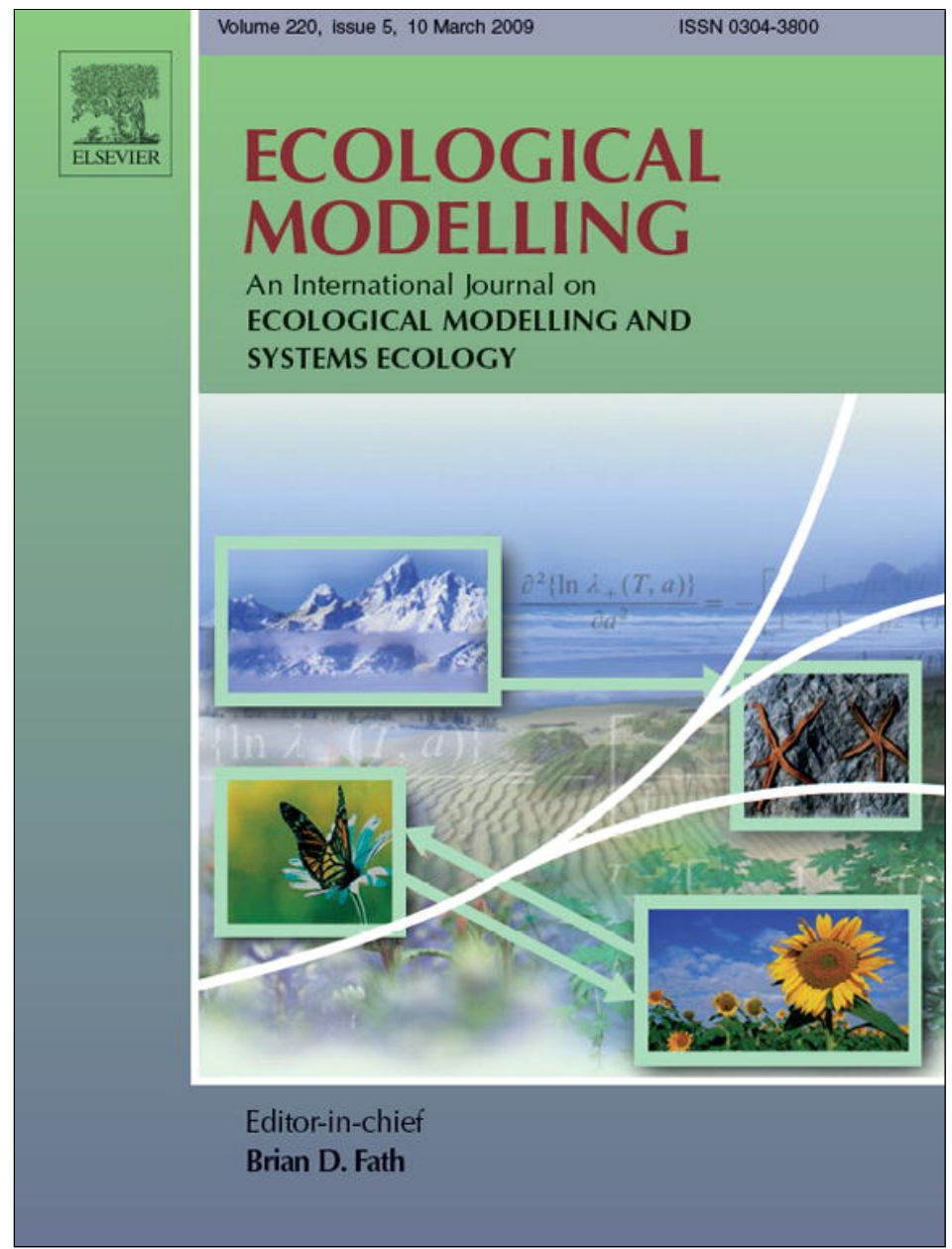

This article appeared in a journal published by Elsevier. The attached copy is furnished to the author for internal non-commercial research and education use, including for instruction at the authors institution and sharing with colleagues.

Other uses, including reproduction and distribution, or selling or licensing copies, or posting to personal, institutional or third party websites are prohibited.

In most cases authors are permitted to post their version of the article (e.g. in Word or Tex form) to their personal website or institutional repository. Authors requiring further information regarding Elsevier's archiving and manuscript policies are encouraged to visit:

http://www.elsevier.com/copyright 


\title{
Transferability of environmental favourability models in geographic space: The case of the Iberian desman (Galemys pyrenaicus) in Portugal and Spain
}

\author{
A. Márcia Barbosa a,b,c,*, Raimundo Real ${ }^{\mathrm{a}}$, J. Mario Vargas ${ }^{\mathrm{a}}$ \\ a Laboratorio de Biogeografía, Diversidad y Conservación, Departamento de Biología Animal, Facultad de Ciencias, Universidad de Málaga, 29071 Málaga, Spain \\ ${ }^{\mathrm{b}}$ Department of Biological Sciences, Imperial College London, Silwood Park Campus, Ascot (Berkshire) SL5 7PY, United Kingdom \\ c Unidade de Macroecologia e Conservação, CEA - Universidade de Évora, Pólo da Mitra, 7002-554 Évora, Portugal
}

\section{A R T I C L E I N F O}

\section{Article history:}

Received 28 March 2008

Received in revised form

26 November 2008

Accepted 5 December 2008

Available online 17 January 2009

\section{Keywords:}

Distribution modelling

Favourability function

Generalized linear models (GLM)

Iberian Peninsula

Model extrapolation

\section{Introduction}

Species distribution models are a valuable and increasingly used tool for environmental management and conservation. Predictive models have a number of interesting potential applications, such as the forecasting of species occurrence in poorly documented regions, the definition of the most adequate areas for species protection or reintroduction, or the prediction of species responses to environmental change (Fielding and Haworth, 1995). These applications may involve applying models outside the region from where the data were taken - that is, model transference in space - since species distribution data are often available from a limited part of the total distribution range, and conservation measures may be necessary in areas where the distribution is not well known.

On the other hand, models built using data from a given geographic area may be less applicable elsewhere, due to local or regional variations in species' responses to the environment (Brown

* Corresponding author at: Department of Biological Sciences, Imperial College London, Silwood Park Campus, Ascot (Berkshire) SL5 7PY, United Kingdom.

Tel.: +44 2075942351; fax: +44 2075942339.

E-mail addresses: a.m.barbosa@imperial.ac.uk, barbosa@uevora.pt (A.M. Barbosa). and Lomolino, 1998; Osborne and Suárez-Seoane, 2002). Bulluck et al. (2006) found that, if model predictions are to be applied to an environmentally similar area and the modelled species' ecological requirements are not too plastic, distribution models may often be reliable outside their original scope. This raises the issue that models may lose applicability in areas where the predictor variables span outside the range of values the model was built on.

Another potential constraint on the transferability of distribution models is the extent and quality of the training data. The extension of a species' distribution within the modelled territory may affect model performance, widespread species being the most difficult to model (Manel et al., 2001; Stockwell and Peterson, 2002; McPherson et al., 2004), although this can be an artefact of model evaluation techniques (Lobo et al., 2008; Jiménez-Valverde et al., 2008). But additionally, models based on a part of the territory where the species' range has no clear geographical limits may not detect important environmental constraints, reducing predictive power when they are extrapolated outside the original area (Segurado and Araújo, 2004; Arntzen, 2006).

The choice of modelling method is another important issue when the aim is to predict distribution in non-sampled areas. Peterson et al. (2007) compared the predictive success of two "presence-only" modelling algorithms, GARP (genetic algorithm for rule-set production) and Maxent (maximum entropy), when 
extrapolated in geographic space. Maxent overfitted to the original data, while GARP slightly overestimated the modelled species' distributions. However, Papeş and Gaubert (2007) showed that, when sample size is small, Maxent can extrapolate more than GARP. Besides, Phillips (2008) further pointed out that Peterson et al.'s (2007) work was strongly affected by geographic bias in the occurrence data used, and affirmed that this is a much greater problem for presence-only than for presence-absence models.

We remark that so-called presence-only methods also take absences into account, in the form of "background data", and are affected by false absences, which are simply true presences that they miss. Besides, models that do explicitly account for absences have a number of advantages, namely computing valuable information on conditions that are in fact unfavourable for the species, and modelling the realized rather than the theoretically potential distribution (Jiménez-Valverde and Lobo, 2006). Species absences in a dataset can be of two types: true, and false. False absences result from insufficient sampling effort given the species' abundance or detectability. They can hinder good model performance, although Reese et al. (2005) showed that randomly distributed false absences, due to randomly biased sampling effort, do not. True absences can be further subdivided into two classes: "true environmental" absences, when the species is not present due to environmental constraints on its physiology; and contingent absences, when the environment is appropriate but other factors such as limitations to dispersal, elimination by anthropogenic or stochastic events, or biotic interactions prevent species occurrence (Jiménez-Valverde et al., 2008). Contingent absences are an important component of species' realized distributions, and accounting for them may provide models with better descriptive and predictive potential, provided that contingent factors are similar in the prediction area.

Furthermore, Meynard and Quinn (2007) showed that generalized linear models (GLM) and generalized additive models (GAM), two presence-absence modelling methods, outperform more complex techniques such as classification trees and GARP, providing a good trade-off between model complexity and performance. Randin et al. (2006) showed that GLM were slightly but significantly more robust to transferability than GAM, suggesting that overfitting may reduce transferability. We too use GLM, widely employed in species distribution modelling (e.g. Teixeira and Arntzen, 2002; Osborne and Suárez-Seoane, 2002; Barbosa et al., 2003; Arntzen and Alexandrino, 2004; Real et al., 2008), as they produce robust models, explicit enough to illustrate which and how predictors are involved, but complex enough to detect subtle spatial patterns within the distribution range.

We also chose a species with marked distribution limits inside a study area, the Iberian Peninsula, divided among two countries, Portugal and Spain. The Iberian desman (Galemys pyrenaicus Geoffroy, 1811) is an endangered insectivore mammal that inhabits lakes, small streams, and rivers in cold mountain environments. It is endemic to the Pyrenees and the Iberian northern half. Its main conservation problems derive from habitat destruction or fragmentation and from predation by an invasive carnivore, the American mink Mustela vison (Gisbert and García-Perea, 2005; Palazón et al., 2005). The Iberian desman is presently considered vulnerable in Portugal (Cabral et al., 2006) and in Spain (Palomo et al., 2007).

We aimed to test the effects of two of the main potential constraints on the success of model transference in space: the completeness of the distribution data, and the analysed range of the predictors. Portugal provides comprehensive desman presence/absence data, derived from a specific survey in which every $10 \mathrm{~km} \times 10 \mathrm{~km}$ UTM grid cell within the species' range was systematically searched for occurrence signs (Queiroz et al., 1998), minimising false absences in the dataset. The Spanish distribution data were taken from a national mammal atlas in which survey effort was not as thorough as in Portugal. The Spanish dataset is thus likely to include more false absences, which we are naturally unable to distinguish reliably from contingent absences. We have, however, reason to believe that false absences are neither numerous nor spatially biased, as this particular species was fairly well studied throughout Spain (Nores et al., 2002).

On the other hand, the range of environmental conditions observed in Portugal is only a subset of those available in Spain, which has a larger surface area and more diverse climate and topography. A model built from Spanish data can, therefore, take into account a wider range of environmental features and be applied to Portugal with practically no limitations in this respect. Conversely, the extrapolation of the Portuguese model to Spain would entail a few predictions outside the function's domain.

We built a model of environmental favourability based on the complete Iberian desman distribution dataset, and one separate model for each of the two countries. We compared the performances of these models to test two alternative hypotheses: (1) Data completeness is more important than the analysed range of predictor variables; in this case, the Portuguese model should be more transferable than the Spanish one and (2) the analysed range of the predictors is more important than a thorough sampling effort; in this case, the Spanish model would have the best results when transferred.

\section{Methods}

\subsection{Study area and base maps}

The Iberian Peninsula is Europe's south-western extremity and covers nearly $600,000 \mathrm{~km}^{2}$, of which $18 \%$ belong to Portugal and $82 \%$ to Spain. Both countries are topographically and climatically heterogeneous, but Spain encompasses a wider range of variation. To define the territorial units we used CartaLinx 1.2 (Clark Labs, USA) and the digital UTM $10 \mathrm{~km} \times 10 \mathrm{~km}$ grid maps obtained, respectively, from the Macroecology and Conservation Unit (former Biological Cartography Lab) of the University of Évora, and from the Area of Protection against Forest Fires of the Spanish Ministry for the Environment. We re-sampled the Portuguese map, initially in a Gauss projection, to the UTM-30N reference system originally adopted for Spain. We appended a digitized perimeter of Portugal to the UTM grid and cut it to eliminate the parts of the UTM squares not included in Portuguese territory, which was already done in the Spanish map. We then appended the Portuguese and Spanish maps and databases, to obtain a third GIS cover with the UTM $10 \mathrm{~km} \times 10 \mathrm{~km}$ squares of the whole Iberian Peninsula.

\subsection{Distribution data and predictor variables}

We used UTM $10 \mathrm{~km} \times 10 \mathrm{~km}$ presence/absence data, obtained from a thorough specific survey in Portugal (Queiroz et al., 1998) and from a mammal atlas in Spain (Nores et al., 2002) (Fig. 1). We recorded 23 predictor variables related to different macroenvironmental factors prone to affect desman distribution (Table 1). According to Austin (1980), predictors can be of three main types: resource variables, i.e. matter or energy directly consumed by the species; direct gradients, i.e. variables that affect the species' physiology; and indirect gradients, which do not affect the species directly but are strongly correlated to direct or resource gradients. The latter are more easily measured and usually replace a combination of different resources and direct gradients in a simple way (Guisan et al., 1999; Guisan and Zimmermann, 2000). Our variables were thus chosen on the basis of availability at this scale and potential predictive power, and are surrogates for more local causal factors (see also Post and Forchhammer, 2002). The inclusion of spatial variables such as latitude and longitude helps 


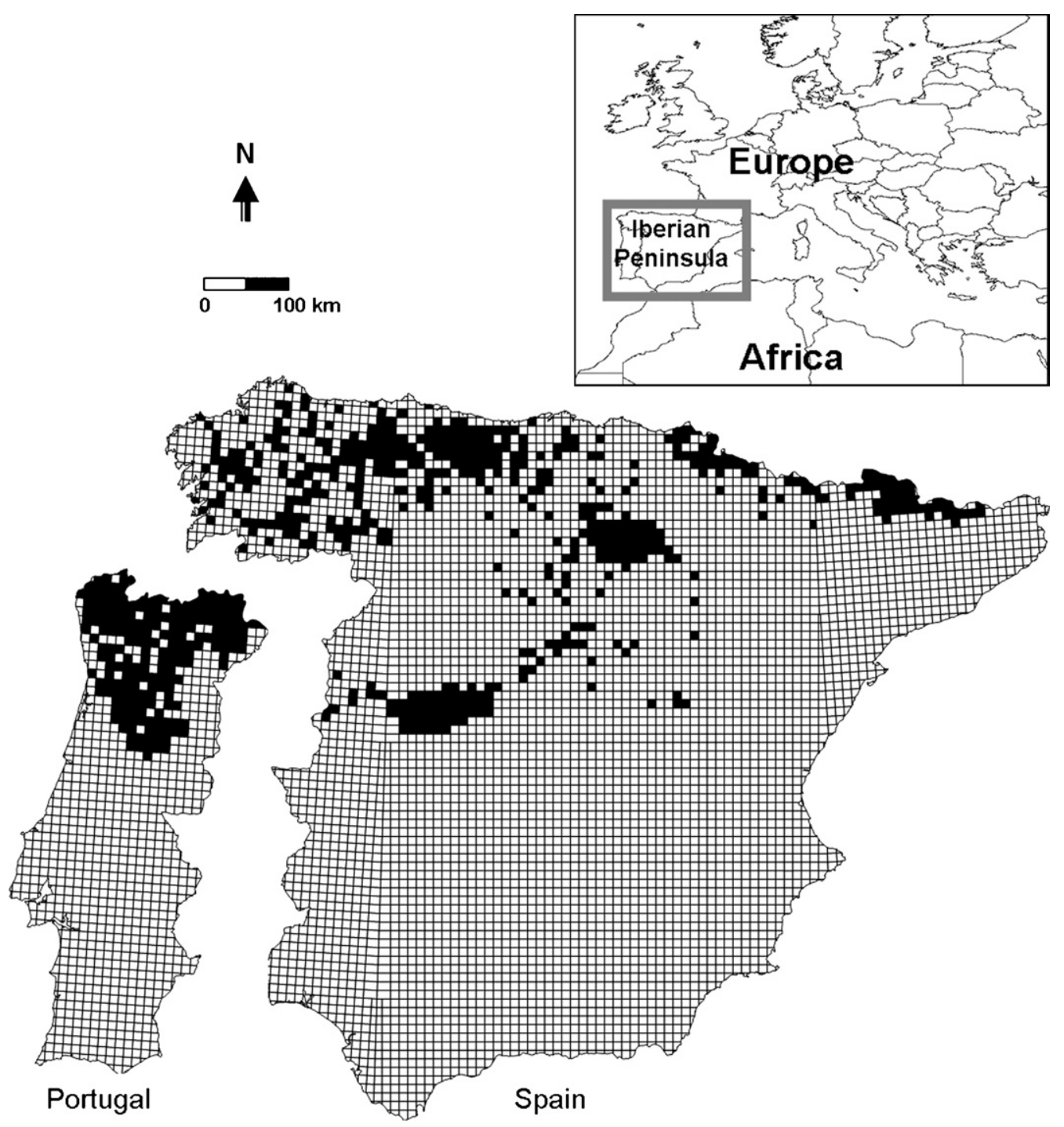

Fig. 1. Location of the study area and Galemys pyrenaicus distribution in Portugal (after Queiroz et al., 1998) and Spain (after Palomo and Gisbert, 2002) on UTM $10 \mathrm{~km} \times 10 \mathrm{~km}$ cells. Black squares represent recorded presences.

model distribution trends not related to the spatial structure in the environmental conditions (Borcard et al., 1992; Diniz-Filho et al., 2003; Kühn, 2007), but rather to historical events or to migrations from favourable areas to those less favourable but within reach (Legendre, 1993; Barbosa et al., 2001; Real et al., 2003).

We digitized (using CartaLinx 1.2) and interpolated (using Idrisi32, Clark Labs, USA) these variables on a $1 \mathrm{~km} \times 1 \mathrm{~km}$ resolution (except for altitude, which is distributed as a digital coverage at this resolution by the Land Processes Distributed Active Archive Center, located at the U.S. Geological Survey's EROS Data Center, https://lpdaac.usgs.gov/), and obtained the mean values of the variables for each UTM $10 \mathrm{~km} \times 10 \mathrm{~km}$ square. Details on the digitizing and interpolation process were explained by Barbosa et al. (2003).

\subsection{Statistical analyses}

We built three distribution models of $G$. pyrenaicus using the data from Portugal, Spain, and the whole Iberian Peninsula, respectively. We used the favourability function of Real et al. (2006), a GLM that computes local variations in species presence probability in relation to overall species prevalence. Unlike logistic regression, it allows using all available data (both presences and absences) while making models independent of the presence/absence ratio in the study area (Real et al., 2006; Jiménez-Valverde and Lobo, 2006). With the favourability function, thresholds for all models are levelled according to the species prevalence in each area. A favourability value of 0.5 means that presence of the species is as probable as its prevalence in the corresponding study area, i.e., neutral environmental favourability. Consequently, the same environmental threshold may be used for all models, with no problem in using uneven presence/absence datasets (Real et al., 2006; JiménezValverde and Lobo, 2006). This can enhance the transferability of models between areas differing in species prevalence.

To avoid a spurious effect of grid cell area on desman presence probability, we excluded from the analyses any UTM cells that were cut by the coastline, the unions between longitudinal UTM zones, or the borders with neighbouring countries, and used only equal-area $100 \mathrm{~km}^{2}$ squares. The number of analysed cells was, therefore, 177 presences +589 absences in Portugal, 448 presences +3995 absences in Spain, and 660 presences +4675 absences in the whole Iberian Peninsula.

Statistical theory predicts an increase of spurious findings when a large number of variables are under analysis, due to the increase of type I error under repeated testing (i.e., the familywise error rate, FWER). García (2003) recommended FWER control in ecological studies by evaluating Benjamini and Hochberg's 
Table 1

Factors and their related variables used to model the distribution of Galemys pyrenaicus, and their range of values in Portugal and Spain (average values on UTM $10 \mathrm{~km} \times 10 \mathrm{~km}$ grid cells).

\begin{tabular}{|c|c|c|c|c|}
\hline Factor & Variable & Code & Range in Portugal & Range in Spain \\
\hline Topography & $\begin{array}{l}\text { Mean altitude }(\mathrm{m})^{\mathrm{a}} \\
\text { Mean slope (degrees) (calculated from Alti) }\end{array}$ & $\begin{array}{l}\text { Alti } \\
\text { Slop }\end{array}$ & $\begin{array}{l}0-1408.6 \\
0.1-11.3\end{array}$ & $\begin{array}{l}0-2630.6 \\
0-19.6\end{array}$ \\
\hline Water availability & $\begin{array}{l}\text { Mean annual precipitation }(\mathrm{mm})^{\mathrm{b}} \\
\text { Mean relative air humidity in January at } 07: 00 \mathrm{~h}(\%)^{\mathrm{b}} \\
\text { Mean relative air humidity in July at } 07: 00 \mathrm{~h}(\%)^{\mathrm{b}}\end{array}$ & $\begin{array}{l}\text { Prec } \\
\text { HJan } \\
\text { HJul }\end{array}$ & $\begin{array}{l}390.1-2557.4 \\
81.3-94.9 \\
50.4-86.6\end{array}$ & $\begin{array}{l}154-2621.3 \\
60.7-95.0 \\
50.6-92.4\end{array}$ \\
\hline Environmental energy & $\begin{array}{l}\text { Mean annual insolation }(\mathrm{h} / \text { year })^{\mathrm{b}} \\
\text { Mean annual solar radiation }\left(\mathrm{kwh} / \mathrm{m}^{2} / \text { day }\right)^{\mathrm{b}} \\
\text { Mean temperature in January }\left({ }^{\circ} \mathrm{C}\right)^{\mathrm{b}} \\
\text { Mean temperature in July }\left({ }^{\circ} \mathrm{C}\right)^{\mathrm{b}} \\
\text { Mean annual temperature }\left({ }^{\circ} \mathrm{C}\right)^{\mathrm{b}} \\
\left.\text { Mean annual number of frost days (minimum temperature } \leq 0^{\circ} \mathrm{C}\right)^{\mathrm{b}} \\
\text { Mean annual potential evapotranspiration }(\mathrm{mm})^{\mathrm{b}}\end{array}$ & $\begin{array}{l}\text { Inso } \\
\text { SRad } \\
\text { TJan } \\
\text { TJul } \\
\text { Temp } \\
\text { DFro } \\
\text { PET }\end{array}$ & $\begin{array}{l}1983.3-3112.5 \\
352.2-509.3 \\
1.5-12.9 \\
15.7-26.2 \\
9.4-17.1 \\
0-74.0 \\
619.1-933.6\end{array}$ & $\begin{array}{l}1603.5-3172.0 \\
304.6-507.0 \\
3.7 \text { to } 13.2 \\
13.5-28.8 \\
3.9-19.4 \\
0-117.7 \\
566.7-1036.4\end{array}$ \\
\hline Productivity & Mean annual actual evapotranspiration $(\mathrm{mm})(=$ minimum $[P E T$, Prec $])$ & AET & $390.1-862.9$ & $154.6-923.9$ \\
\hline Environmental disturbance & $\begin{array}{l}\text { Maximum precipitation in } 24 \mathrm{~h}(\mathrm{~mm})^{\mathrm{b}} \\
\text { Relative maximum precipitation }(=M P 24 / \text { Prec })\end{array}$ & $\begin{array}{l}M P 24 \\
R M P\end{array}$ & $\begin{array}{l}76.2-323.4 \\
0.1-0.3\end{array}$ & $\begin{array}{l}52.1-474.5 \\
0.1-1.0\end{array}$ \\
\hline Climatic variability & $\begin{array}{l}\text { Mean annual number of days with precipitation } \geq 0.1 \mathrm{~mm}^{\mathrm{b}} \\
\text { Annual temperature range }\left({ }^{\circ} \mathrm{C}\right)(=\text { TJul }- \text { TJan }) \\
\text { Annual relative air humidity range }(\%)(=\mid \text { HJan }- \text { HJul } \mid)\end{array}$ & $\begin{array}{l}\text { DPre } \\
\text { TRan } \\
\text { HRan }\end{array}$ & $\begin{array}{l}61.5-148.7 \\
7.0-19.9 \\
0.5-41.6\end{array}$ & $\begin{array}{l}16.1-193.2 \\
8.2-21.5 \\
0.1-41.3\end{array}$ \\
\hline Human activity & $\begin{array}{l}\text { Distance to the nearest highway }(\mathrm{km})^{c} \\
\text { Distance to the nearest town with more than } 100,000 \text { inhabitants }(\mathrm{km})^{c} \\
\text { Distance to the nearest town with more than } 500,000 \text { inhabitants }(\mathrm{km})^{c}\end{array}$ & $\begin{array}{l}\mathrm{DHi} \\
\text { U100 } \\
\text { U500 }\end{array}$ & $\begin{array}{l}0.9-84.5 \\
1.0-166.4 \\
1.6-206.9\end{array}$ & $\begin{array}{l}0.5-105.2 \\
0.1-154.0 \\
0.1-301.9\end{array}$ \\
\hline Spatial situation & $\begin{array}{l}\text { Latitude }\left({ }^{\circ} \mathrm{N}\right)^{\mathrm{c}} \\
\text { Longitude }\left({ }^{\circ} \mathrm{E}\right)^{\mathrm{c}}\end{array}$ & $\begin{array}{l}\text { Lati } \\
\text { Long }\end{array}$ & $\begin{array}{l}37.0-42.1 \\
-9.5 \text { to }-6.2\end{array}$ & $\begin{array}{l}36.1-43.7 \\
-9.3 \text { to } 3.3\end{array}$ \\
\hline
\end{tabular}

Sources: aU.S. Geological Survey (1996); ${ }^{b}$ Font (1983, 2000); ${ }^{\mathrm{C}}$.G.N. (1999); data on the number of inhabitants of urban centers taken from Enciclopédia Universal (http://www.universal.pt) for Portugal and from the Instituto Nacional de Estadística (http://www.ine.es) for Spain, both in 1999.

(1995) false discovery rate (FDR). We controlled this error using the procedure for all forms of dependency among test statistics (Benjamini and Yekutieli, 2001), and only accepted variables under a FDR value lower than 0.05 .

Regressions were performed using forward-backward stepwise variable selection (see Pearce and Ferrier, 2000), with a 0.05 significance threshold for inclusion and 0.10 for exclusion. Stepwise selection is commonly used in distribution modelling (e.g. Araújo et al., 2005; Bulluck et al., 2006; Arntzen, 2006) as it maximizes predictive efficiency in an objective and reproducible way and is a useful and effective tool when the individual importance of each variable is not known a priori (Hosmer and Lemeshow, 2000). Although correlations exist between the variables, the forward-backward procedure adds at each step only variables with a significant additional contribution to the model, i.e., significantly related to the residuals not accounted for by other correlated variables. It also drops terms that do not degrade the fit by a significant amount. In addition, correlations between predictors affect coefficients, but not the predictive ability of the model, which can actually profit from including the possibility to add correlated variables (Legendre and Legendre, 1998, p. 519).

We checked that the last step produced the most parsimonious model according to Akaike's Information Criterion (AIC; Akaike, 1973, see Brotons et al., 2004). This procedure was used with a predictive rather than explanatory goal, and accuracy of model predictions was considered more important than significance of particular ecological terms (see Legendre and Legendre, 1998; Brotons et al., 2004).

As the utility of models cannot be captured by a single accuracy measure (Moisen and Frescino, 2002), we compared the performance of the models when applied to each of the three territories using five evaluation measures: the overall correct classification rate (CCR), sensitivity (i.e., the correct classification rate for presences), specificity (correct classification rate for absences), Cohen's kappa, and the area under the ROC curve (AUC) (see Fielding and Bell, 1997).

\section{Results}

The model obtained from the Portuguese distribution data included six variables, the Spanish model included eight variables, and the complete Iberian model included thirteen variables. Seven of the variables were common to at least two of the models (Table 2). The three models' predictions on the whole Iberian Peninsula are shown in Fig. 2, and their evaluation scores in each of the three territories are shown in Fig. 3.

The Portuguese model achieved the highest scores for descriptive capacity in its own territory for all five evaluation measures

Table 2

Variables and their associated coefficients $(\beta)$ in the three Galemys pyrenaicus environmental favourability models.

\begin{tabular}{|c|c|c|}
\hline Portuguese model & Spanish model & Iberian model \\
\hline & Alti $^{6}(0.0021)$ & $\operatorname{AET}^{11}(0.0038)$ \\
\hline \multicolumn{3}{|l|}{$D_{F r o}^{2}(0.10)$} \\
\hline $\operatorname{DPre}^{6}(0.043)$ & $\begin{array}{l}\text { DPre }^{3}(0.027) \\
\text { HJul }^{4}(-0.10)\end{array}$ & $\begin{array}{l}\operatorname{DPre}^{7}(0.032) \\
\operatorname{HRan}^{10}(0.039) \\
\operatorname{Inso}^{12}(0.0014)\end{array}$ \\
\hline \multirow[t]{2}{*}{ Lati $^{1}$ (2.43) } & $\operatorname{Lati}^{5}$ (1.13) & $\begin{array}{l}\operatorname{Lati}^{4}(1.56) \\
\operatorname{Long}^{2}(-0.35) \\
\text { MP24 }^{9}(0.0051) \\
\operatorname{PET}^{13}(-0.0063)\end{array}$ \\
\hline & $\operatorname{Prec}^{1}(0.00077)$ & \\
\hline $\operatorname{Slop}^{4}(0.23)$ & $\begin{array}{l}\operatorname{SRad}^{8}(0.013) \\
\operatorname{Temp}^{2}(-0.60) \\
\operatorname{TJan}^{7}(0.43)\end{array}$ & $\begin{array}{l}\operatorname{Slop}^{3}(0.24) \\
\operatorname{SRad}^{6}(0.020) \\
\operatorname{Temp}^{1}(-0.55)\end{array}$ \\
\hline $\begin{array}{l}\operatorname{TJul}^{5}(0.57) \\
U 500^{3}(-0.019)\end{array}$ & Constant $(-4463)$ & $\begin{array}{l}T J u l^{8}(0.36) \\
U 500^{5}(-0.0093)\end{array}$ \\
\hline
\end{tabular}

Numbers in superscript indicate the order of inclusion in the model. All variables had significant $(p<0.01)$ Wald test values. Variable codes as in Table 1. 


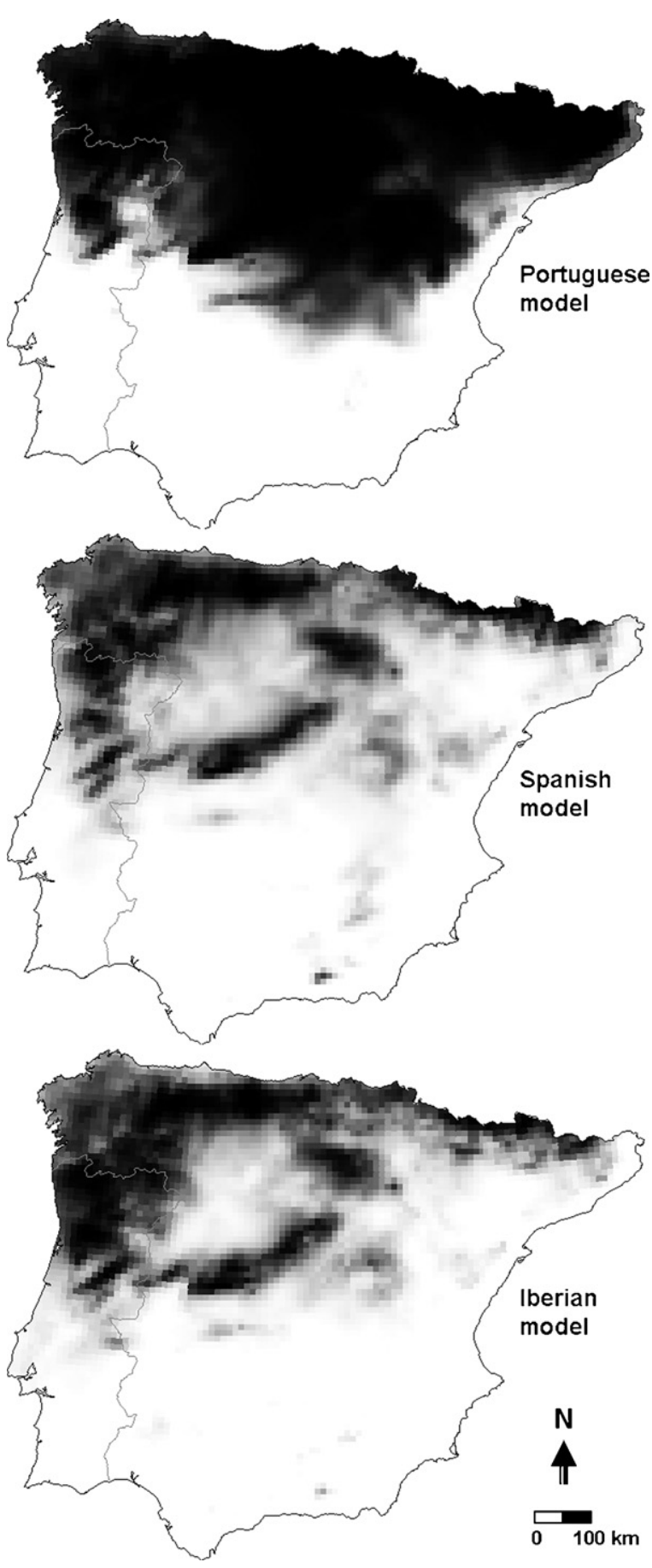

Fig. 2. Environmental favourability for Galemys pyrenaicus in the Iberian Peninsula according to the models obtained using the data from Portugal, Spain and the whole Peninsula. Favourability values are represented with a greyscale ranging from 0 (white) to 1 (black).

(Fig. 3, top). However, and despite relying on comprehensive distribution data, it scored the lowest predictive scores when extrapolated (Fig. 3, bottom), clearly overestimating desman distribution in Spain (cf. Figs. 1 and 2). If we consider only the UTM cells in which all selected variables are within the Portuguese function's domain (i.e., within the range of values observed in Portugal; Table $1 ; N=1738$ ), the Portuguese model evaluation scores improve in this "Portugal-like" Iberian Peninsula, compared to the model extrapolated to the whole Peninsula, but they do not when we consider only the extrapolation to "Portugal-like" Spain $(N=867)$ compared to the extrapolation to the whole of Spain (Fig. 3, bottom).
However, this is likely due to the fact that the only four presences in areas classified as unfavourable by the Portuguese model in Spain were within the function's domain, with a strong effect on sensitivity and related measures.

Despite relying on a less even sampling effort and probably containing more false absences, the Spanish model achieved generally good descriptive performance (Fig. 3, top) and also showed better predictive capacity than the Portuguese model when extrapolated (Fig. 3, bottom). In fact, it achieved nearly the same descriptive scores as the Iberian model, except for kappa, which was visibly inferior (Fig. 3, top). However, kappa values are known to be influenced by species prevalence in the territory where predictions are applied (see Thompson and Walter, 1988), so they are not directly comparable. Desman prevalence in Spain was just under $10 \%$, whereas in the whole Iberian Peninsula it reached $12 \%$. Indeed, prevalence correlated quite significantly with kappa values across all models (Pearson's $r=0.846, p=0.001, N=11$ ), whereas it correlated moderately with CCR, specificity, and AUC $(p<0.05)$ and did not correlate with sensitivity $(p>0.5)$.

\section{Discussion}

The transference of models to predict into broadly unsampled regions is quite a bigger challenge than simply interpolating or filling gaps in a generally sampled landscape (Peterson et al., 2007). All three models analysed here were the best at describing desman distribution in their own territory (Fig. 3). These results are consistent with those of Osborne and Suárez-Seoane (2002), who attributed them to local variations in the species' response to the environment. Regional models can detect these local variations more effectively than global ones, which have to incorporate in a single model a greater heterogeneity in environment-species relationships. However, the Iberian model achieved results comparable to those of the national models in both territories (Figs. 2 and 3), indicating that the differences between Portugal and Spain, at least concerning the environmental factors that affect the Iberian desman, are not so sharp as to let an Iberian-scale model be markedly affected by the environmental heterogeneity within this area.

Vaughan and Ormerod (2003) argued that modelling success depends on sampling the whole region of environmental space within which the organism is present. Not including part of this range in the models may result in computing species response curves different to the real ones, thus restraining model application outside its original scope. However, distribution data (and predictor variables) are often available from a limited part of the species' range, which is why transferable models are needed in the first place.

On the other hand, Arntzen and Alexandrino (2004) and Arntzen (2006) argued that a model with a good descriptive ability (i.e., a good fit to the starting data, evidenced by good intrinsic evaluation measures) will probably be effective when extrapolated outside its original scope. Arntzen (2006), in particular, compared several distribution models obtained from Portugal and found that the best descriptive models were also the best predictive ones when extrapolated to Spain. However, our results show that this conclusion may not be general, unless we are only comparing models built from the same base territory. When extrapolated outside their original geographical area, our two national models behaved in different ways. Although the Portuguese model scored the highest descriptive evaluation measures, it was the worst when extrapolated to the neighbouring territory (Fig. 3), visibly overestimating the prediction of favourable areas in Spain (cf. Figs. 1 and 2). The Spanish model, albeit scoring lower in the intrinsic evaluation measures, was generally more effective at predicting desman distribution in Portugal (cf. Figs. 1 and 2). 

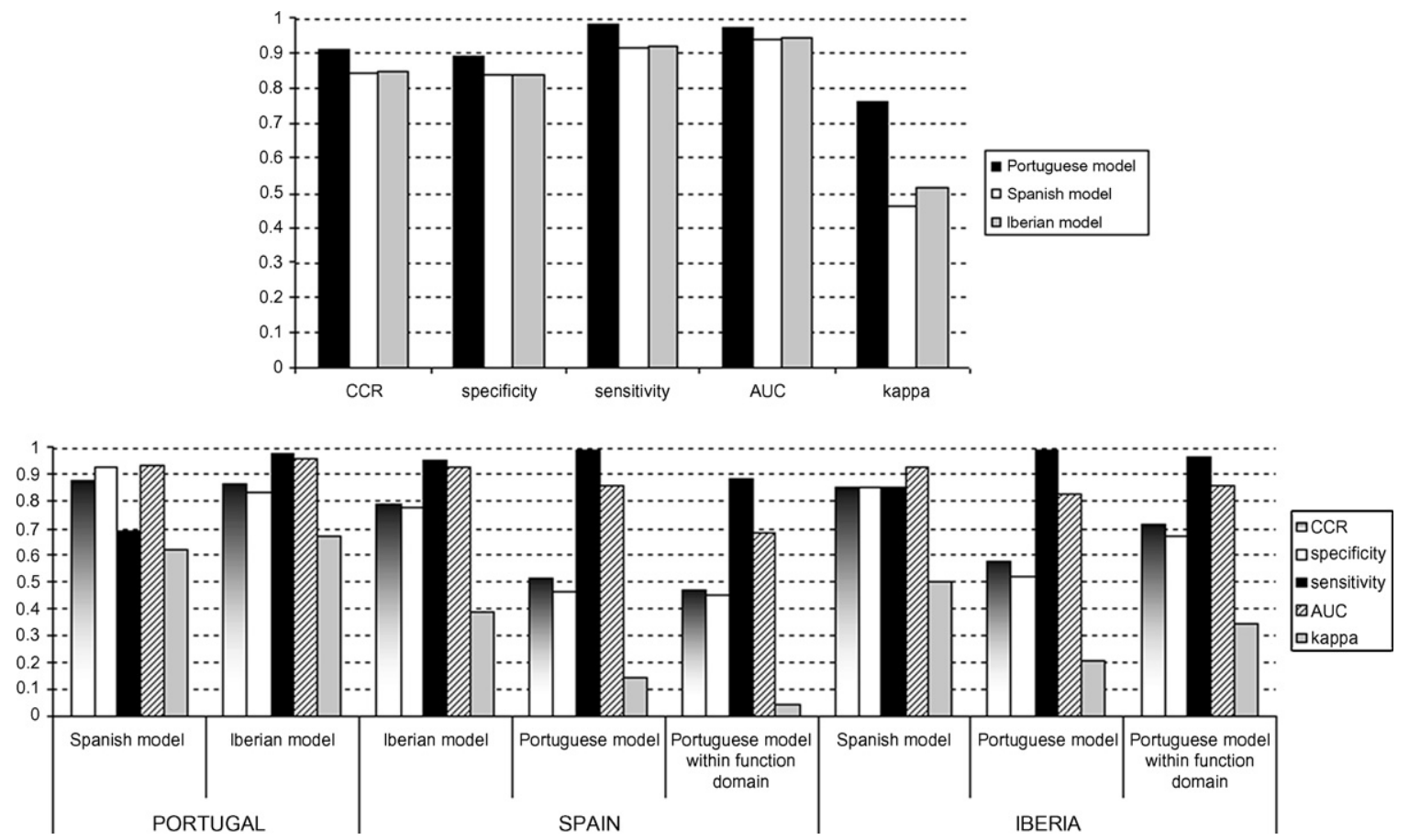

Fig. 3. Evaluation scores for each Galemys pyrenaicus distribution model in its own territory (top) and when spatially extrapolated (bottom). For details see text.

Possible causes for this asymmetric transferability may be of two types: environmental differences between geographic regions, and biotic factors specific to the modelled species and the regional species pool it interacts with (Randin et al., 2006). Environmental differences do exist in this case, as Portugal includes only part of the variation observed in Spain. Some of the variables take values in Spain that clearly exceed the domain of a Portuguese function (Table 1), and models may yield unrealistic predictions outside this domain. Additionally, as Portugal is clearly smaller than Spain, with a significantly lower number of grid cells (i.e. observations; Fig. 1), the Portuguese model includes fewer variables (Table 2), overlooking details that the Spanish model succeeds to detect and that are noticeable only when a larger geographical area is analysed. Furthermore, Spain contains combinations of environmental factors that do not occur in Portugal, as for example, a combination of high mean altitude with low mean slope along a vast plateau, the Meseta, which the Portuguese model cannot take into account. This can explain the marked differences between observed desman distribution in the Meseta area (northern-central Peninsula, Fig. 1) and the favourability predicted for this region by the Portuguese model (Fig. 2): the Portuguese model predicted the whole area to be favourable, whereas the species is markedly absent.

Biotic differences exist as well, as Spain is witnessing a more widespread expansion of an introduced predator, the American mink (Mustela vison), which has a negative impact on desman populations (Palomo and Gisbert, 2002; Palazón et al., 2005). This predator may be behind a number of the desman's contingent absences in Spain, which the Portuguese model is unable to predict. Although the Spanish model also could not access mink distribution explicitly, it may have included environmental proxies (indirect gradients; Austin, 1980; Guisan et al., 1999) that accounted for its effect. It would be interesting, though, to obtain up-to-date information on the distribution of this invasive predator in order to build comparative predator-prey distribution models (e.g. Real et al., 2008), and/or to include it among the predictors of desman distribution.

Despite relying on comprehensive distribution data, the Portuguese model extrapolated worse than the Spanish one (Fig. 3), showing that a high-quality dataset, with virtually no false absences, does not warrant extrapolation success. The good transference results of the Spanish model, on the other hand, indicate that false absences are not such an important constraint, as long as they are not too many and not geographically biased, as we believe to be the case here (Nores et al., 2002). False absences resulted mainly from lower detectability of the species in some areas, and thus are probably related to species abundance. Real et al. (2008) showed that favourability models based on the same distribution atlas used here correlated significantly with independent abundance data for two other mammal species. Actually, imperfect but abundance-related detection may even be convenient for obtaining abundance estimates by modelling presence data. A "perfect" dataset, with all actual presences and absences correctly recorded regardless of local abundance, could be less useful to model abundance and might actually overpredict species distribution.

We therefore conclude that the analysed range of values of the predictors is, at least in some cases, more important than a dataset free of false absences. In any case, comparison of the present results with other model extrapolations performed over the same area (Teixeira et al., 2001; Arntzen, 2006) or elsewhere (e.g. Peterson et al., 2007) proves this method to yield fairly reliable and extrapolable models. GLMs are here shown to be a balanced modelling technique, yielding models complex enough to detect the relevant trends in species distributions but simple enough to let the modeller understand which and how are the factors involved. Perhaps more importantly, they produce models flexible enough to detect non-linear responses of the species to the environment, but constrained enough to avoid modelling stochastic variation in the training data, so avoiding modelling the "noise" together with the "signal".

The use of geopolitical units allowed us to test the influence of differences in sampling-effort design on model transferability. However, models based on this kind of units may be more biased than those based on natural biogeographical units, which may be preferred whenever possible, especially if the main aim is to produce transferable models.

We must bear in mind that the success of predictive models outside their original scope depends on several factors, not all of 
which can be taken into account by modelling a single species, as was already pointed out by Randin et al. (2006). Here we have tested model transferability using a species whose distribution is fairly well documented, in Spain as well as in Portugal. Besides, desman distribution has marked limits within both of the studied territories, which has allowed obtaining models with high descriptive capacity and, consequently, with a fair possibility of predictive success after extrapolation. The same would probably not occur with more widespread species, with more gaps in the distribution data and without clear limits within the study area (Segurado and Araújo, 2004; Arntzen, 2006). Studies on model transferability should, therefore, be complemented with others focusing on such wide-ranging species. Nevertheless, the application of transferred models in conservation planning is usually needed for species facing conservation problems, whose distributions are usually not so wide. Large-scale GIS models can outline the main characteristics of these species' distribution areas and be used to predict environmental favourability in regions where their distribution is less documented. Generalized linear models, and the favourability function in particular, seem a promising and reliable method to perform such analyses.

\section{Acknowledgments}

This work was supported by the project CGL2006-09567/BOS (Ministerio de Educación y Ciencia, Spain, and FEDER). We thank Maria Grade, Claudia Soares and Carlos Nores for information on available desman distribution data. A.M.B.'s research was funded by the Portuguese Fundação para a Ciência e a Tecnologia (fellowships SFRH/BD/4601/2001 and SFRH/BPD/40387/2007).

\section{References}

Akaike, H., 1973. Information theory and an extension of the maximum likelihood principle. In: Petrov, B.N., Csaki, F. (Eds.), Proceedings of the Second International Symposium on Information Theory. Akadémia Kiadó, Budapest, Hungary, pp. 267-281.

Araújo, M.B., Thuiller, W., Williams, P.H., Reginster, I., 2005. Downscaling European species atlas distributions to a finer resolution: implications for conservation planning. Global Ecol. Biogeogr. 14, 17-30.

Arntzen, J.W., 2006. From descriptive to predictive distribution models: a working example with Iberian amphibians and reptiles. Frontiers Zool. 3, 8

Arntzen, J.W., Alexandrino, J., 2004. Ecological modelling of genetically differentiated forms of the Iberian endemic Golden-striped salamander, Chioglossa lusitanica. Herpetol. J. 14, 137-141.

Austin, M.P., 1980. Searching for a model for use in vegetation analysis. Vegetatio 42, $11-21$

Barbosa, A.M., Real, R., Márquez, A.L., Rendón, M.A., 2001. Spatial, environmental and human influences on the distribution of otter (Lutra lutra) in the Spanish provinces. Diversity Distrib. 7, 137-144.

Barbosa, A.M., Real, R., Olivero, J., Vargas, J.M., 2003. Otter (Lutra lutra) distribution modeling at two resolution scales suited to conservation planning in the Iberian Peninsula. Biol. Conserv. 114, 377-387.

Benjamini, Y., Hochberg, Y., 1995. Controlling the false discovery rate: a practical and powerful approach to multiple testing. J. Royal Stat. Soc. B 57, 289-300.

Benjamini, Y., Yekutieli, D., 2001. The control of the false discovery rate in multiple testing under dependency. Ann. Stat. 29, 1165-1188.

Borcard, D., Legendre, P., Drapeau, P., 1992. Partialling out the spatial component of ecological variation. Ecology 73, 1045-1055.

Brotons, L., Thuiller, W., Araújo, M.B., Hirzel, A., 2004. Presence-absence versus presence-only modelling methods for predicting bird habitat suitability. Ecography $27,437-448$.

Brown, J.H., Lomolino, M.V., 1998. Biogeography, second ed. Sinauer Associate, Sunderland, MA, USA, xii+691 pp.

Bulluck, L., Fleishman, E., Betrus, C., Blair, R., 2006. Spatial and temporal variations in species occurrence rate affect the accuracy of occurrence models. Global Ecol. Biogeogr. 15, 27-38.

Cabral, M.J. (coord.), Almeida, J., Almeida, P.R., Dellinger, T., Ferrand de Almeida, N. Oliveira, M.E., Palmeirim, J.M., Queiroz, A.L., Rogado, L., Santos-Reis, M. (Eds.), 2006. Livro Vermelho dos Vertebrados de Portugal. Instituto de Conservação da Natureza, Lisboa, Portugal.

Diniz-Filho, J.A.F., Bini, L.M., Hawkins, B.A., 2003. Spatial autocorrelation and red herrings in geographical ecology. Global Ecol. Biogeogr. 12, 53-64.

Fielding, A.H., Bell, J.F., 1997. A review of methods for the assessment of prediction errors in conservation presence/absence models. Environ. Conserv. 24, 38 49.
Fielding, A.H., Haworth, P.F., 1995. Testing the generality of bird-habitat models. Cons. Biol. 9, 1466-1481.

Font, I., 1983. Atlas climático de España. Instituto Nacional de Meteorología, Madrid, Spain, $48 \mathrm{pp}$.

Font, I., 2000. Climatología de España y Portugal. Ediciones Universidad de Salamanca, Salamanca, Spain, 422 pp.

García, L.V., 2003. Controlling the false discovery rate in ecological research. Trends Ecol. Evol. 18, 553-554.

Gisbert, J., García-Perea, R., 2005. Distribución y factores de amenaza del desmán ibérico, Galemys pyrenaicus, en Extremadura. In: Sociedad Española para la Conservación y el Estudio de los Mamíferos (Ed.), Libro de resúmenes VII Jornadas de la Sociedad Española para la Conservación y Estudio de los Mamíferos. SECEM, Málaga, Spain, pp. 98.

Guisan, A., Zimmermann, N.E., 2000. Predictive habitat distribution models in ecology. Ecol. Model. 135, 147-186.

Guisan, A., Weiss, S.B., Weiss, A.D., 1999. GLM versus CCA spatial modeling of plant species distribution. Plant Ecol. 143, 107-122.

Hosmer, D.W., Lemeshow, S., 2000. Applied Logistic Regression, second ed. John Wiley and Sons, New York, NY, USA, 392 pp.

I.G.N., 1999. Mapa de carreteras. Península Ibérica, Baleares y Canarias. Instituto Geográfico Nacional/Ministerio de Fomento, Madrid, Spain, 1 pp.

Jiménez-Valverde, A., Lobo, J.M., 2006. The ghost of unbalanced species distribution data in geographical model predictions. Diversity Distrib. 12, 521-524.

Jiménez-Valverde, A., Lobo, J.M., Hortal, J., 2008. Not as good as they seem: the importance of concepts in species distribution modelling. Diversity Distrib. 14, $885-890$.

Kühn, I., 2007. Incorporating spatial autocorrelation may invert observed patterns. Diversity Distrib. 13, 66-69.

Legendre, P., 1993. Spatial autocorrelation: trouble or new paradigm? Ecology 74, 1659-1673.

Legendre, P., Legendre, L., 1998. Numerical Ecology, second ed. Elsevier, Amsterdam, The Netherlands, $x v+853 \mathrm{pp}$.

Lobo, J.M., Jiménez-Valverde, A., Real, R, 2008. AUC: a misleading measure of the performance of predictive distribution models. Global Ecol. Biogeogr. 17, 145-151.

Manel, S., Williams, H.C., Ormerod, S.J., 2001. Evaluating presence-absence models in ecology: the need to account for prevalence. J. Appl. Ecol. 38, 921-931.

McPherson, J., Jetz, W., Rogers, D.J., 2004. The effects of species' range sizes on the accuracy of distribution models: ecological phenomenon or statistical artefact? J. Appl. Ecol. 41, 811-823.

Meynard, C.N., Quinn, J.F., 2007. Predicting species distributions: a critical comparison of the most common statistical models using artificial species. J. Biogeogr. $34,1455-1469$.

Moisen, G.G., Frescino, T.S., 2002. Comparing five modelling techniques for predicting forest characteristics. Ecol. Model. 157 (2-3), 209-225.

Nores, C., Queiroz, A.I., Gisbert, J., 2002. Galemys pyrenaicus (E. Geoffroy Saint-Hilaire, 1811). In: Palomo, L.J., Gisbert, J. (Eds.), Atlas de los Mamíferos Terrestres de España. Dirección General de Conservación de la Naturaleza- SECEM-SECEMU, Madrid, Spain, pp. 70-73.

Osborne, P.E., Suárez-Seoane, S., 2002. Should data be partitioned spatially before building large-scale distribution models? Ecol. Model. 157, 249-259.

Palazón, S., Gómez, A., López de Luzuriaga, J., Temiño, C., Alarcia, O., Carreras, J., Pinedo, J., Lopo, L., Arjona, L., Minobis, B., Melero, Y., Ruiz-Olmo, J., Gosálbez, J., 2005. Distribución, estatus y control del visón americano (Mustela vison) en el norte de España. In: Sociedad Española para la Conservación y el Estudio de los Mamíferos (Ed.), Libro de resúmenes VII Jornadas de la Sociedad Española para la Conservación y Estudio de los Mamíferos. SECEM, Málaga, Spain, p. 156.

Palomo, L.J., Gisbert, J. (Eds.), 2002. Atlas de los mamíferos terrestres de España. Dirección General de Conservación de la Naturaleza-SECEM-SECEMU, Madrid, Spain, 564 pp.

Palomo, L.J., Gisbert, J., Blanco, J.C., 2007. Atlas y libro rojo de los mamíferos terrestres de España. Dirección General para la Biodiversidad-SECEM-SECEMU, Madrid, Spain, 588 pp.

Papeş, M., Gaubert, P., 2007. Modelling ecological niches from low numbers of occurrences: assessment of the conservation status of poorly known viverrids (Mammalia, Carnivora) across two continents. Diversity Distrib. 13, 890902 .

Pearce, J., Ferrier, S., 2000. An evaluation of alternative algorithms for fitting species distribution models using logistic regression. Ecol. Model. 128, 127-147.

Peterson, A.T., Papeş, M., Eaton, M., 2007. Transferability and model evaluation in ecological niche modeling: a comparison of GARP and Maxent. Ecography 30, $550-560$.

Phillips, S.J., 2008. Transferability, sample selection bias and background data in presence-only modelling: a response to Peterson et al. (2007). Ecography 31, 272-278.

Post, E., Forchhammer, M.C., 2002. Synchronization of animal population dynamics by large-scale climate. Nature $420,168-171$.

Queiroz, A.I., Quaresma, C.M., Santos, C.P., Barbosa, A.J., Carvalho, H.M., 1998. Bases para a conservação da toupeira-de-água, Galemys pyrenaicus. Estudos de Biologia e Conservação da Natureza, No. 27. ICN, Lisbon, Portugal, 118 pp.

Randin, C.F., Dirnböck, T., Dullinger, S., Zimmermann, N.E., Zappa, M., Guisan, A., 2006. Are niche-based species distribution models transferable in space? J. Biogeogr. 33, 1689-1703.

Real, R., Barbosa, A.M., Porras, D., Kin, M.S., Márquez, A.L., Guerrero, J.C., Palomo, L.J., Justo, E.R., Vargas, J.M., 2003. Relative importance of environment, human activity and spatial situation in determining the distribution of terrestrial mammal diversity in Argentina. J. Biogeogr. 30, 939-947. 
Real, R, Barbosa, A.M. Vargas, J.M., 2006. Obtaining environmental favourability functions from logistic regression. Environ. Ecol. Stat. 13, 237-245.

Real, R., Barbosa, A.M., Rodríguez, A., García, F.J., Vargas, J.M., Palomo, L.J., Delibes, M., 2008. Conservation biogeography of ecologically interacting species: the case of the Iberian lynx and the European rabbit. Diversity Distrib. (early view), doi:10.1111/j.1472-4642.2008.00546.x.

Reese, G.C., Wilson, K.R., Hoeting, J.A., Flather, C.H., 2005. Factors affecting species distribution predictions: a simulation modeling experiment. Ecol. Appl. 15, 554-564.

Segurado, P., Araújo, M.B., 2004. An evaluation of methods for modelling species distributions. J. Biogeogr. 31, 1555-1568.

Stockwell, D.R.B., Peterson, A.T., 2002. Effects of sample size on accuracy of species distribution models. Ecol. Model. 148, 1-13.
Teixeira, J Arntzen, JW. 2002. Potential impact of climate warming on the distribution of the Golden-striped salamander, Chioglossa lusitanica, on the Iberian Peninsula. Biodiversity Conserv. 11, 2167-2176.

Teixeira, J., Ferrand, N., Arntzen, J.W., 2001. Biogeography of the golden-striped salamander, Chioglossa lusitanica: a field survey and spatial modelling approach. Ecography 24, 618-623.

Thompson, W.D., Walter, S.D., 1988. A reappraisal of the kappa coefficient. J. Clin. Epidemiol. 41 (10), 949-958.

U.S. Geological Survey, 1996. GTOPO30. Land Processes Distributed Archive Center http://edcdaac.usgs.gov/gtopo30/gtopo30.asp.

Vaughan, I.P., Ormerod, S.J., 2003. Improving the quality of distribution models for conservation by addressing shortcomings in the field collection of training data. Cons. Biol. 17, 1601-1611. 